\title{
Palliative surgery in a patient diagnosed with trisomy 18 and rare neurological
} comorbidities

\section{Abstract}

Introduction: The authors describe a case of a patient with a prenatal diagnosis of Trisomy 18 with atypical manifestation, rare anomalies of the central nervous system and subsequent surgical treatment.

Case presentation: The infant was diagnosed with holoprosencephalia, schizencephalia, corpus callosum agenesis and severe hydrocephalus. No significant heart, gastrointestinal or kidney defects were found. Being in otherwise good condition, the patient was qualified for a ventriculi-peritoneal shunt surgery due to rapidly increasing head circumference. Following the uneventful operation patient's parents reported a general improvement in their child condition.

Conclusions: Bearing in mind the possibility of complications and the child's poor prognosis, the reasons for surgical intervention were evaluated, as well as the possible outcomes of withholding invasive treatment. Discussion over the benefits of palliative surgery and the risk of 'palliative harm' illustrate how selected children benefit from an interventionist approach.

Palliat Med Pract 2021; 15, 1: 76-79

Keywords: trisomy 18, Edwards syndrome, hydrocephalus, schizencephaly, holoprosencephalia, palliative surgery

\section{Abbreviations}

T18 - trisomy 18

$\mathrm{CT}$ - computed tomography

$\mathrm{MRI}$ - magnetic resonance imaging

RLV - right lateral ventricle

LLV - left lateral ventricle

CrUSS - a cranial ultrasound scan

AST - aspartate transaminase

ALT — alanine transaminase

$$
\begin{aligned}
& \text { Hgb - haemoglobin } \\
& \text { CSF - cerebrospinal fluid }
\end{aligned}
$$

\section{Introduction}

Hydrocephalus is defined as active distension of the ventricular system resulting from the inadequate passage of cerebrospinal fluid from its point of production within the cerebral ventricles to its point of absorption into the systemic circulation [1]. This

\section{Address for correspondence:}

Paula Szenejko

Medical University of Gdańsk

Marii Skłodowskiej-Curie 3a, 80-210 Gdańsk, Polska

e-mail: paula.szenejko@gmail.com

Palliative Medicine in Practice 2021; 15, 1, 76-79

Copyright (C) Via Medica, ISSN 2545-0425

DOI: 10.5603/PMPI.2021.0003

This article is available in open access under Creative Common Attribution-Non-Commercial-No Derivatives 4.0 International (CC BY-NC-ND 4.0) license, allowing to download articles and share them with others as long as they credit the authors and the publisher, but without permission to change them in any way or use them commercially. 
complex condition affects 1.1 in 1,000 infants [2]. Causes of congenital hydrocephalus include genetic mutations, neural tube defects, presence of intracranial cysts, the concomitance of other brain malformations, and chromosomal abnormalities such as trisomy 13, 18, or 21 [3]. Hydrocephalus, however, is a rather unusual finding among patients diagnosed with Trisomy 18 (T18) [4]. Irrespectively of aetiology, the condition is treated with shunt placement, most commonly ventriculi-abdominal, which is a low-risk procedure, followed by a moderately high rate of complications [5].

Trisomy 18, or Edwards Syndrome, is the second most common chromosomal disorder after Trisomy 21. It consists of minor anomalies, major malformations, growth delay, concomitant with psychomotor and cognitive developmental delay. About $90 \%$ of patients present with congenital heart defect [6]. Less frequent are gastrointestinal defects and central nervous system abnormalities, among which cerebellar hypoplasia, agenesis of the corpus callosum, polymicrogyria, spina bifida were reported [7]. Based on the available literature, schizencephaly has not been reported in patients diagnosed with T18. This lethal condition is characterized by the presence of abnormal clefts and slits in the cerebral hemispheres [8]. Medial survival range for T18 patients was estimated at 3-14 days with a $5-10 \%$ chance of surviving more than 1 year [7]. There has been observed a paradigm shift in the treatment of patients with T18. A recent review compares survival with a palliative approach ( $12.3 \%$ at 5 years) vs an interventionist approach (23\% at 5 years) in these infants [9].

\section{Case presentation}

The female neonate with prenatally diagnosed $\mathrm{T} 18$, born to gravida 2, para 1 mother, was delivered spontaneously at 34 weeks gestation with a bodyweight of $2100 \mathrm{~g}$. Neonate condition was severe - Apgar score at 1 minute was 3 . The baby's vital functions improved and 5 minutes after birth Apgar increased to 8 . On physical examination, the infant presented distinctive phenotypic traits of T18 and macrocephaly with a head circumference of $36 \mathrm{~cm}$ that had been increasing thereafter.

Thus, a head CT was taken shortly after birth. The scan revealed several anomalies: holoprosencephaly, which is incomplete separation of the forebrain, agenesis of the corpus callosum and severe hydrocephalus. The only abnormality detected during echocardiography was clinically insignificant aortic stenosis. Being able to breathe and eat on her own, the newborn was discharged home for palliative care.
Due to a rapidly increasing head circumference $(6 \mathrm{~cm}$ since birth, $3 \mathrm{~cm}$ in the following week), a 1-month old patient was admitted to the hospital for additional examinations. Cranial ultrasound showed supratentorial hydrocephalus. Therefore, surgical consultation was requested, and further examinations were advised.

In the MRI scans the hydrocephalus affected mostly RLV, LLV was shifted $6 \mathrm{~mm}$ leftwards and of the size of $17 \mathrm{~mm}$. The third ventricle was enlarged up to $21 \mathrm{~mm}$. The fourth ventricle and cerebral aqueduct were stenotic. Lack of septum pellucidum and agenesis of the corpus callosum was observed. Moreover, above the right lateral ventricle lack of brain tissue was recorded. A suggested diagnosis was open-lip schizencephaly. Despite severe neurological findings, the child was in overall good condition. Parents had not observed vomiting, petulance or somnolence. Being on formula, the infant was eating eagerly, gaining weight.

The patient was then admitted to the paediatric surgery ward for implantation of a ventriculo-abdominal shunt. The procedure was uneventful. One day after the surgery the newborn was in average condition. Due to anaemia (Hgb $8.7 \mathrm{~g} / \mathrm{dl}$ ), she received packed red blood cells transfusion, intravenous fluids and passive oxygen therapy. Six days after the procedure the patient was in good condition, willing to eat. The newborn was discharged from the hospital. CrUSS were stable after the procedure - the shunt was placed centrally in RLV, which constituted the majority of cranial space, LLV was narrow - up to $5 \mathrm{~mm}$ width and $14 \mathrm{~mm}$ height, visible brain stem and cerebellum were pressured by fluid collection towards foramen magnum. The third ventricle was widely open toward lateral ventricles.

What was beneficial for the child was the stabilization of head circumference to $43 \mathrm{~cm}$ and the possibility of bottle-feeding. The child during outpatient visits was described as active and alert. Unfortunately, the child contracted a respiratory tract infection with Bordetella pertussis in the 6th month of life, during which a nasogastric tube was a necessity. On the last recorded visit, however, the parents did not report new problems with care after the infant. The child was being fed mostly with a bottle and partially via a nasogastric tube. Satisfactory weight gain up to $4415 \mathrm{~g}$ in the 8th month was observed and is supervised in a nutrition counselling centre. No problems with the valve were observed.

\section{Discussion}

In recent years the approach towards T18 has changed profoundly. Since 2010 T18 is no longer listed 
in conditions for which resuscitation is not indicated in Neonatal Resuscitation Guidelines [10]. However, the explanation for the change of this status was not provided [6]. Furthermore, Cereda and Silberberg urge to stop using the term 'lethal' for T18 $[7,9]$. The authors claim it as misleading, as $3-13.4 \%$ of neonates survive more than 1 year only with palliative care (excluding palliative surgeries) [9]. Moreover, parents are generally optimistic about the quality of life of their children [7, 9]. Unfortunately, even though survival as long as 16 years has been reported, the overall developmental age of survivors is similar to that of 6-8 months children [7].

\section{Estimating the outcome of surgical treatment}

To discuss the legitimacy of surgical treatment of hydrocephalus for this we should first discuss the likely outcome of invasive intervention. Unfortunately, there is no available data regarding the prevalence and management of the condition in T18 patients. However, research on surgical treatment of other malformations is available and might be useful for the discussion.

Spierson et al. described 6 infants who underwent surgical treatment of gastrointestinal malformations with 5 of them discharged home [11]. The authors concluded that based on their experience T18 should not be a contraindication to surgical intervention. The desired outcome of surgical treatment for those patients was a better quality of palliative care, improved the quality of short life and discharge from hospital [11]. With such a limited number of cases, however, the paper does not provide sufficient evidence for a general conclusion. Nonetheless, this view is supported by Silberberg [9].

Several papers on cardiac operations performed on patients with T18 stated that surgical interventions can be justified as they prolong survival. However, Graham undermined the credibility of those conclusions [6]. Firstly, there is weak evidence for a causative relationship between surgical intervention and a longer lifespan. While the most frequent cause of death is central apnoea, cardiac diseases account for only $11 \%$ of deaths [7]. It was impossible to conclude that cardiac surgery was the reason for improved survival, as at the time of surgery the patients survived longer than the vast majority of others. Secondly, it is arguable whether a promise for longer life can be a reasonable justification for surgery. The intellectual disability remains profound and no surgical management can improve this result. Moreover, the intervention did not alter the 'discharge alive' rate. Some patients spend more than half of their life in hospital due to surgery. Recently the British Supreme Court agreed that "to die in the course of futile aggressive treatment" is against neonate's best interest and unnecessary medical interventions "would deprive him of his mother's cuddles for the rest of his short life" [12].

Although the procedure itself does not involve much pain and risk, more than half of the shunts block at least once over ten years. Moreover, during this period there is a $20 \%$ risk of infection, which is a serious condition, most often requiring hospitalization and revision surgery, that is much more complicated than the first operation [5]. Thus, despite relatively short hospitalisation and uneventful postoperative period, it cannot be ruled out that the intervention would contribute to a lower quality of life.

\section{Estimating the outcome of refraining from surgical treatment}

The second issue to be addressed is what would have been the outcome if the shunt had not been inserted. Due to the lack of relevant data, it is impossible to determine whether untreated hydrocephalus increases the risk of death in this patient. However, consequences of withstanding invasive treatment include a greater degree of physical, cognitive, sensory disability, and motor dysfunctions due to an enlarged head. In this particular patient, it could have been manifested as a loss of ability to eat by herself, possibly following the need for nasogastric tube feeding. These deficits could only be worsened with the brain malformations described. That could have been described as palliative harm, particularly after the decision to take the child home, which the literature describes as an important quality of life objective for parents of infants with T18 [9].

Even though at that moment the only complaint was increasing head circumference, raised CSF pressure invariably results in increased cerebral pressure. The symptoms include headache, vomiting, convulsions. However, in Jaykar and Patil experience less than $19 \%$ in $0-2$ years age group manifested those features [13]. As a possible appearance of the symptoms would cause deterioration in the quality of life, surgery constitutes a valid preventive intervention. Furthermore, the patient has already survived longer than the majority of other children with T18. Moreover, while the neonate does not present with typical malformations for this chromosome, she is not likely to die of cardiac or kidneys dysfunction. While central apnea remains the main concern, it is probable that the child survives long enough to experience unpleasant symptoms of increased CSF pressure. 


\section{Conclusions}

It is unknown whether palliative shunt surgery in patients with T18 prevents the possible development of more profound disability. Nonetheless, surgery in this case probably facilitated weight gain and allowed partial oral feeding. Preventing the onset of symptoms of increased CSF pressure, which would complicate palliative care, is in all likelihood a benefit to this patient. Given the scarcity of data relevant to this unique and complex case and the fact that no surgical intervention can change a child's poor prognosis, the final decision should be left to the patient's legal guardians. However, they deserve clinical guidance and assistance from their physicians in establishing the goals of care. Awareness of the benefits of palliative surgery and understanding the risk of 'palliative harm' after withholding it are crucial.

\section{Conflict of interests}

The authors declare no conflict of interest.

\section{Funding}

This study has no funding.

No identifiable information about the patient is included in the manuscript.

\section{References}

1. Rekate HL. The definition and classification of hydrocephalus: a personal recommendation to stimulate debate. Cerebrospinal Fluid Res. 2008; 5: 2, doi: 10.1186/17438454-5-2, indexed in Pubmed: 18211712.

2. Munch T, Rostgaard K, Rasmussen ML, et al. Familial aggregation of congenital hydrocephalus in a nationwide cohort. Brain. 2012; 135(8): 2409-2415, doi: 10.1093/brain/aws158.

3. Tully HM, Dobyns WB. Infantile hydrocephalus: a review of epidemiology, classification and causes. Eur J Med Genet. 2014; 57(8): 359-368, doi: 10.1016/j.ejmg.2014.06.002, indexed in Pubmed: 24932902.

4. Metwalley KA, Farghalley HS, Abd-Elsayed AA. Congenital hydrocephalus in an Egyptian baby with trisomy 18: a case report. J Med Case Rep. 2009; 3: 114, doi: 10.1186/17521947-3-114, indexed in Pubmed: 19946592.

5. Wilkinson D. Ethical Dilemmas in Postnatal Treatment of Severe Congenital Hydrocephalus. Camb Q Healthc Ethics. 2016; 25(1): 84-92, doi: 10.1017/\$0963180115000316, indexed in Pubmed: 26788949.

6. Graham E. Niemowlęta z Trisomią 18 i złożonymi wrodzonymi wadami serca nie powinny poddawać się otwartej operacji serca. J Law Medicine Ethics. 2016; 44(2): 286-291.

7. Cereda A, Carey J. Zespół trisomii 18. Orphanet J Rare Dis. 2012; 7(1): 81

8. Rege SV, Patil H. Bilateral giant open-lip schizencephaly: A rare case report. J Pediatr Neurosci. 2016; 11(2): 128-130, doi: 10.4103/1817-1745.187638, indexed in Pubmed: 27606022.

9. Silberberg A, Robetto J, Grimaux G, et al. Ethical issues about the paradigm shift in the treatment of children with trisomy 18. Eur J Pediatr. 2020; 179(3): 493-497, doi: 10.1007/s00431019-03531-4, indexed in Pubmed: 31814050.

10. Kattwinkel J, Perlman JM, Aziz K, et al. American Heart Association. Neonatal resuscitation: 2010 American Heart Association Guidelines for Cardiopulmonary Resuscitation and Emergency Cardiovascular Care. Pediatrics. 2010; 126(5): e1400-e1413, doi: 10.1542/peds.2010-2972E, indexed in Pubmed: 20956432.

11. Spierson H, Masood Y, Craigie RJ, et al. Trisomy 18: palliative surgical intervention. Arch Dis Child. 2018; 103(10): 1001, doi: 10.1136/archdischild-2017-313889, indexed in Pubmed: 29449215.

12. Dyer C. Parents fail to overturn ruling not to resuscitate baby. BMJ. 2005; 330(7498): 985, doi: 10.1136/bmj.330.7498. 985-b, indexed in Pubmed: 15860816.

13. Jaykar R, Patil S. Indications of ventriculoperitoneal shunt: a prospective study. International Surgery Journal. 2017; 4(4): 1319, doi: 10.18203/2349-2902.isj20171135. 


\section{Paliatywny zabieg chirurgiczny}

\section{u pacjentki z rozpoznaniem trisomii 18 i rzadkimi współistniejącymi schorzeniami neurologicznymi}

Artykuł jest tłumaczeniem pracy: Szenejko P., Anzelewicz S., Czauderna P. Palliative surgery inpatient diagnosed with trisomy 18 and rare neurological comorbidities. Palliat. Med. Pract. 2021, tom 15, nr 1: 76-79.

Należy cytować wersję pierwotną.

\section{Streszczenie}

Wstęp: W pracy opisano przypadek pacjentki z prenatalnym rozpoznaniem trisomii 18 o nietypowej manifestacji i z rzadkimi anomaliami ośrodkowego układu nerwowego oraz leczenie chirurgiczne.

Opis przypadku: $U$ niemowlęcia rozpoznano holoprozencefalię, schizencefalię, niewykształcenie ciała modzelowatego oraz ciężkie wodogłowie. Nie stwierdzono poważnych wad serca, układu pokarmowego i nerek. Ponieważ poza powyższym stan pacjentki był dobry, zakwalifikowano ją do założenia zastawki komorowo-otrzewnowej ze względu na gwałtownie powiększający się obwód głowy. Po operacji, która przebiegła bez komplikacji, rodzice pacjentki zauważyli ogólną poprawę stanu zdrowia dziecka.

Wnioski: Mając na uwadze możliwość wystąpienia powikłań oraz złe rokowanie u dziecka, oceniono przyczyny interwencji chirurgicznej oraz możliwe skutki powstrzymania się leczenia inwazyjnego. Dyskusja dotycząca korzyści z operacji paliatywnych oraz ryzyka „szkody paliatywnej” ilustruje, w jaki sposób niektóre dzieci mogą odnieść korzyść z podejścia interwencyjnego.

Palliat Med Pract 2021; 15, 1: 80-83

Słowa kluczowe: trisomia 18, zespół Edwardsa, hydrocefalia, schizencefalia, holoprozencefalia, operacja paliatywna

\section{Skróty}

T18 - trisomia 18

CT (computed tomography) - tomografia komputerowa
MRI (magnetic resonance imaging) - obrazowanie rezonansem magnetycznym

RLV (right lateral ventricle) - prawa komora boczna LLV (left lateral ventricle) - lewa komora boczna

\section{Adres do korespondencji:}

Paula Szenejko

Uniwersytet Medyczny w Gdańsku

Marii Skłodowskiej-Curie 3a, 80-210 Gdańsk, Polska

e-mail: paula.szenejko@gmail.com 
CrUSS (a cranial ultrasound scan) - USG przezciemiączkowe

AST (aspartate transaminase) - transaminaza asparginianowa

ALT (alanine transaminase) - transaminaza alaninowa $\mathrm{Hgb}$ - hemoglobina

CSF (cerebrospinal fluid) - płyn mózgowo-rdzeniowy

\section{Wstęp}

Wodogłowie definiowane jest jako aktywne rozstrzenie układu komorowego, wynikające $z$ niewłaściwego przepływu płynu mózgowo-rdzeniowego z miejsca jego produkcji w komorach mózgowych do miejsca jego absorpcji do krążenia systemowego [1]. To złożone schorzenie dotyka 1,1 na 1000 dzieci [2]. Przyczyny wrodzonego wodogłowia obejmują mutacje genetyczne, wady cewki nerwowej, obecność torbieli wewnątrzczaszkowych, współistnienie innych wad deformacyjnych w mózgu oraz nieprawidłowości chromosomalne, takie jak trisomia 13, 18 lub 21 [3]. Występowanie wodogłowia jest jednak dość niezwykłe wśród pacjentów, u których zdiagnozowano trisomię 18 (T18) [4]. Niezależnie od etiologii schorzenie leczy się przez założenie zastawki, najczęściej komorowo-otrzewnowej; zabieg ten jest obarczony niskim ryzykiem i wiąże się z umiarkowanie wysokim odsetkiem powikłań [5].

Trisomia 18, czyli zespół Edwardsa, jest drugim najczęściej występującym zaburzeniem chromosomalnym po trisomii 21 . Na schorzenie to składają się drobne nieprawidłowości, znaczne deformacje i opóźnienie wzrostu, którym towarzyszy opóźnienie rozwojowe w zakresie zdolności poznawczych i psychomotorycznych. U około $90 \%$ pacjentów występuje wrodzona wada serca [6]. Rzadziej pojawiają się wady układu pokarmowego i nieprawidłowości w ośrodkowym układzie nerwowym, wśród których opisywano między innymi hipoplazję móżdżku, niewykształcenie ciała modzelowatego, polimikrogyrię i rozszczep kręgosłupa [7]. W dostępnej literaturze nie ma wzmianek o schizencefalii u pacjentów ze zdiagnozowaną trisomią 18. Ta śmiertelna choroba charakteryzuje się występowaniem nieprawidłowych rozszczepów i szczelin w półkulach mózgu [8]. Szacuje się, że pacjenci z T18 żyją średnio od 3 do 14 dni. Szanse na przeżycie powyżej jednego roku wynoszą 5-10\% [7]. Zaobserwowano zmianę paradygmatu leczenia pacjentów $z$ T18. W ramach przeprowadzonego niedawno przeglądu porównano czas przeżycia u pacjentów, u których stosowano opiekę paliatywną $(12,3 \%$ w wieku 5 lat) oraz pacjentów, u których zastosowano leczenie interwencyjne ( $23 \% \mathrm{w}$ wieku 5 lat) [9].

\section{Opis przypadku}

Noworodek płci żeńskiej o masie ciała $2100 \mathrm{~g}$ $z$ prenatalnie rozpoznanym $\mathrm{T} 18, \mathrm{z}$ drugiej ciąży mat$\mathrm{ki}$, urodził się spontanicznie w 34. tygodniu ciąży. Stan dziecka był ciężki - wynik w skali Apgar w pierwszej minucie wynosił 3 . Funkcje życiowe uległy poprawie i po 5 minutach po urodzeniu wynik na skali Apgar wzrósł do 8. W trakcie badania fizykalnego u noworodka wykryto cechy fenotypowe charakterystyczne dla T18 i makrocefalii. Obwód głowy wynosił $36 \mathrm{~cm}$, a następnie powiększał się.

Wykonano CT głowy krótko po narodzinach. Badanie wykazało kilka nieprawidłowości: holoprozencefalię, czyli niepełne oddzielenie przodomózgowia, niewykształcenie ciała modzelowatego oraz ciężkie wodogłowie. Jedyną nieprawidłowością wykrytą podczas echokardiografii było klinicznie nieistotne zwężenie aorty. Ponieważ noworodek był w stanie samodzielnie oddychać $\mathrm{i}$ jeść, został wypisany do domu, gdzie miał zostać objęty opieką paliatywną. Ze względu na szybko powiększający się obwód głowy ( $6 \mathrm{~cm}$ od urodzenia, $3 \mathrm{~cm}$ w następnym tygodniu), jednomiesięczna pacjentka została przyjęta do szpitala w celu wykonania dodatkowych badań. Badanie USG czaszki wykazało wodogłowie nadnamiotowe. W związku z tym zwrócono się z prośbą o konsultację chirurgiczną oraz zalecono dalsze badania.

Rezonans magnetyczny ujawnit, że wodogłowie dotknęło przede wszystkim RLV, LLV była przesunięta o $6 \mathrm{~mm}$ w lewo i miała wielkość $17 \mathrm{~mm}$. Trzecia komora powiększona była do $21 \mathrm{~mm}$. Czwarta komora i akwedukt mózgowy były zwężone. Zaobserwowano brak przegrody przezroczystej oraz niewykształcenie ciała modzelowatego. Ponadto, ponad prawą boczną komorą stwierdzono brak tkanki mózgowej. Sugerowana diagnozą była schizencefalia typu „otwarte usta". Pomimo poważnych wad neurologicznych dziecko było w ogólnie dobrym stanie. Rodzice nie zaobserwowali wymiotów, drażliwości ani senności. Dziecko karmione było mlekiem modyfikowanym, jadło chętnie i przybierało na wadze.

Pacjentkę przyjęto na oddział chirurgii dziecięcej w celu założenia zastawki komorowo-otrzewnowej. Zabieg przebiegł bez problemów. Dzień po operacji noworodek był w średnim stanie. Ze względu na anemię ( $\mathrm{Hgb} 8,7 \mathrm{~g} / \mathrm{dl}$ ) u dziecka wykonano transfuzję koncentratu krwinek czerwonych, podano dożylnie płyny oraz zastosowano bierną tlenoterapię. Sześć dni po zabiegu pacjentka była w stanie dobrym, wykazywała chęć do jedzenia. Noworodek został wypisany ze szpitala. Wyniki CrUSS po zabiegu były stabilne - zastawkę umieszczono centralnie w RLV, która stanowiła większość przestrzeni czaszkowej. Lewa 
komora boczna była wąska - do $5 \mathrm{~mm}$ szerokości oraz 14 wysokości, zebrany płyn wywierał nacisk na widoczny pień mózgu i móżdżek w kierunku otworu wielkiego. Trzecia komora była szeroko otwarta w kierunku komór bocznych.

Korzyścią dla dziecka było ustabilizowanie obwodu głowy na poziomie $43 \mathrm{~cm}$ oraz możliwość karmienia butelką. Podczas wizyt ambulatoryjnych dziecko opisywane było jako aktywne i czujne. Niestety, w 6 . miesiącu życia wystąpiło zakażenie dróg oddechowych pałeczką Bordetella pertussis, w przebiegu którego konieczne było założenie rurki nosowo-żołądkowej. Podczas ostatniej zarejestrowanej wizyty rodzice nie zgłaszali jednak problemów związanych z opieką nad dzieckiem. Dziecko było karmione głównie butelką oraz częściowo przez rurkę nosowo-żołądkową. Odnotowano satysfakcjonujący przyrost masy ciała do $4415 \mathrm{~g} \mathrm{w}$ 8. miesiącu życia. Dziecko znajduje się pod opieką poradni żywieniowej. Nie zaobserwowano problemów z zastawką.

\section{Dyskusja}

W ostatnich latach podejście do T18 uległo głębokiej zmianie. Od 2010 roku T18 nie jest wymieniana wśród chorób, w przypadku których resuscytacja nie jest zalecana według Wytycznych Dotyczących Resuscytacji Noworodków [10]. Nie wyjaśniono jednak tej zmiany statusu [6]. Ponadto, Cereda i Silberberg postulują zaprzestanie stosowania terminu „śmiertelny" dla T18 [7, 9]. Autorzy twierdzą, że termin ten wprowadza w błąd, ponieważ 3-13,4\% noworodków przeżywa ponad rok wyłącznie przy opiece paliatywnej (z wyłączeniem operacji paliatywnych) [9]. Ponadto, rodzice generalnie wypowiadają się optymistycznie na temat jakości życia ich dzieci $[7,9]$. Niestety, mimo że odnotowuje się przypadki dożycia 16 lat, w zakresie ogólnego wieku rozwojowego chorzy, którzy przeżywają przypominają dzieci w wieku 6-8 miesięcy [7].

\section{Oszacowanie wyników leczenia chirurgicznego}

Aby omówić zasadność leczenia chirurgicznego wodogłowia, należy najpierw omówić prawdopodobny rezultat interwencji inwazyjnej. Niestety, brak jest danych dotyczących częstości występowania oraz postępowania z chorobą u pacjentów z T18. Istnieją jednak badania dotyczące leczenia chirurgicznego innych wad, które mogą być przydatne w dyskusji.

Spierson i wsp. opisali 6 przypadków niemowląt poddanych leczeniu chirurgicznemu wad układu pokarmowego; pięcioro z nich zostało wypisanych do domu [11]. Autorzy stwierdzili, że na podstawie ich doświad- czeń, T18 nie powinno stanowić przeciwwskazania do interwencji chirurgicznej. Pożądanym efektem leczenia u pacjentów była lepsza jakość opieki paliatywnej, wyższa jakość ich krótkiego życia oraz wypisanie ich ze szpitala [11]. Jednak, ze względu na tak ograniczona liczbę przypadków, badanie to nie dostarcza wystarczających dowodów na wyciągnięcie ogólnych wniosków. Pogląd znajduje jednak poparcie Silberberga [9].

W kilku pracach dotyczących operacji serca przeprowadzonych u pacjentów z T18 stwierdzono, że interwencje chirurgiczne mogą być uzasadnione z uwagi na fakt, że wydłużają pacjentom życie. Wiarygodność tych wniosków została jednak podważona przez Grahama [6]. Po pierwsze dowody na związek przyczynowy pomiędzy interwencją chirurgiczną a dłuższym czasem przeżycia są nikłe. Najczęstszą przyczyną śmierci jest bezdech centralny, choroby serca są przyczyną jedynie około $11 \%$ zgonów [7]. Nie można było stwierdzić, że operacja serca była przyczyną dłuższego czasu przeżycia pacjentów, ponieważ w czasie, gdy przeprowadzano operację, pacjenci przeżywali dłużej niż zdecydowana większość. Po drugie, wątpliwe jest czy dłuższy czas przeżycia stanowi racjonalne uzasadnienie dla operacji. Niepełnosprawność intelektualna chorych pozostaje głęboka i żadna interwencja chirurgiczna nie jest w stanie przynieść w tym zakresie poprawy. Co więcej, interwencja nie zmieniła wskaźnika żywych pacjentów wypisanych do domu. Niektórzy pacjenci spędzają z powodu zabiegu ponad połowę życia w szpitalu. Brytyjski Sąd Najwyższy uznał niedawno, że „śmierć w trakcie uporczywego, agresywnego leczenia" jest sprzeczna z najlepszym interesem noworodka, a zbędne interwencje medyczne „mogą go pozbawić ramion matki do końca jego krótkiego życia" [12].

Mimo że sama procedura nie wiąże się z dużym bólem i ryzykiem, ponad połowa zastawek blokuje się przynajmniej raz na dziesięć lat. Ponadto, w tym okresie istnieje 20-procentowe ryzyko infekcji, będącej poważnym stanem, najczęściej wymagającym hospitalizacji oraz zabiegu rewizji, znacznie bardziej skomplikowanego niż pierwszy operacja [5]. Zatem, pomimo stosunkowo krótkiego okresu hospitalizacji i spokojnego okresu po operacji, nie można wykluczyć, że interwencja przyczyni się do obniżenia jakości życia.

\section{Oszacowanie rezultatów zaniechania leczenia chirurgicznego}

Druga kwestią, którą należy omówić, są rezultaty niezałożenia zastawki. Ze względu na brak odpowiednich danych nie da się określić, czy nieleczone wodogłowie zwiększa ryzyko śmierci u pacjenta. Niemniej jednak, konsekwencje braku leczenia inwazyjnego obejmują wyższy stopień upośledzenia fizycznego, po- 
znawczego i sensorycznego oraz dysfunkcji ruchowych spowodowanych powiększoną głową. U tej konkretnej pacjentki mogło się to objawić utratą zdolności samodzielnego jedzenia, być może w następstwie konieczności karmienia jej przez rurkę nosowo-żołądkową. Deficyty te mogą dodatkowo ulec pogłębieniu ze względu na opisane wady mózgu. Można to określić mianem szkody paliatywnej, szczególnie po podjęciu decyzji o zabraniu dziecka do domu, co według literatury stanowi dla rodziców dziecka z T18 istotny cel w zakresie jakości życia [9].

Choć jedynym problemem było powiększanie się obwodu głowy, podwyższone ciśnienie płynu mózgowo-rdzeniowego niezmiennie prowadzi do podniesienia ciśnienia w mózgu. Objawy obejmują ból głowy, wymioty, drgawki. Jednak według Jaykara i Patila występowało to u mniej niż 19\% dzieci w wieku od 0-2 lat [13]. Ponieważ ewentualne wystąpienie objawów mogłoby spowodować pogorszenie jakości życia, operacja pozostaje ważną interwencją profilaktyczną. Co więcej, czas przeżycia pacjentki był dłuższy niż w przypadku innych dzieci z T18. Ponadto, noworodek nie wykazuje typowych dla tego chromosomu wad, nie jest prawdopodobne, że umrze z powodu upośledzonej funkcji nerek lub serca. Bezdech centralny pozostaje głównym problemem, jednak istnieje prawdopodobieństwo, że dziecko przeżyje wystarczająco długo by doświadczyć nieprzyjemnych objawów związanych z podwyższonym ciśnieniem płynu mózgowo-rdzeniowego.

\section{Wnioski}

Nie wiadomo, czy przeprowadzenie paliatywnej operacji założenia zastawki u pacjenta z T18 zapobiega ewentualnemu rozwojowi głębszej niepełnosprawności. Niemniej jednak, w tym przypadku zabieg prawdopodobnie ułatwił przyrost masy ciała i umożliwił częściowe żywienie doustne. Zapobieganie wystąpieniu objawów podwyższonego ciśnienia płynu mózgowo-rdzeniowego, które może komplikować opiekę paliatywną, stanowi najprawdopodobniej korzyść dla pacjentki. Biorąc pod uwagę deficyt danych dotyczących tego wyjątkowego i złożonego przypadku oraz fakt, że brak interwencji chirurgicznej może zmienić złe rokowania u dziecka, ostateczną decyzję powinno się pozostawić jego opiekunom prawnym. Powinni oni jednak otrzymać od lekarzy wskazówki i pomoc w ustalaniu celów w zakresie opieki. Świadomość korzyści płynących z operacji paliatywnej oraz rozumienie ryzyka „szkody paliatywnej” po zaniechaniu operacji mają kluczowe znaczenie.

\section{Konflikt interesów}

Autorzy deklarują brak konfliktu interesów

\section{Finansowanie}

To badanie nie zostało sfinansowane.

Manuskrypt nie zawiera informacji, które mogłyby umożliwić identyfikację pacjenta.

\section{Piśmiennictwo}

1. Rekate HL. The definition and classification of hydrocephalus: a personal recommendation to stimulate debate. Cerebrospinal Fluid Res. 2008; 5: 2, doi: 10.1186/17438454-5-2, indexed in Pubmed: 18211712.

2. Munch T, Rostgaard K, Rasmussen ML, et al. Familial aggregation of congenital hydrocephalus in a nationwide cohort. Brain. 2012; 135(8): 2409-2415, doi: 10.1093/brain/aws158.

3. Tully HM, Dobyns WB. Infantile hydrocephalus: a review of epidemiology, classification and causes. Eur J Med Genet. 2014; 57(8): 359-368, doi: 10.1016/j.ejmg.2014.06.002, indexed in Pubmed: 24932902.

4. Metwalley KA, Farghalley HS, Abd-Elsayed AA. Congenital hydrocephalus in an Egyptian baby with trisomy 18: a case report. J Med Case Rep. 2009; 3: 114, doi: 10.1186/17521947-3-114, indexed in Pubmed: 19946592.

5. Wilkinson D. Ethical Dilemmas in Postnatal Treatment of Severe Congenital Hydrocephalus. Camb Q Healthc Ethics. 2016; 25(1): 84-92, doi: 10.1017/\$0963180115000316, indexed in Pubmed: 26788949.

6. Graham E. Niemowlęta z Trisomią 18 i złożonymi wrodzonymi wadami serca nie powinny poddawać się otwartej operacji serca. J Law Medicine Ethics. 2016; 44(2): 286-291.

7. Cereda A, Carey J. Zespół trisomii 18. Orphanet J Rare Dis. 2012; 7(1): 81

8. Rege SV, Patil H. Bilateral giant open-lip schizencephaly: A rare case report. J Pediatr Neurosci. 2016; 11(2): 128130, doi: 10.4103/1817-1745.187638, indexed in Pubmed: 27606022

9. Silberberg A, Robetto J, Grimaux G, et al. Ethical issues about the paradigm shift in the treatment of children with trisomy 18. Eur J Pediatr. 2020; 179(3): 493-497, doi: 10.1007/s00431-019-03531-4, indexed in Pubmed: 31814050

10. Kattwinkel J, Perlman JM, Aziz K, et al. American Heart Association. Neonatal resuscitation: 2010 American Heart Association Guidelines for Cardiopulmonary Resuscitation and Emergency Cardiovascular Care. Pediatrics. 2010; 126(5): e1400-e1413, doi: 10.1542/peds.2010-2972E, indexed in Pubmed: 20956432.

11. Spierson H, Masood Y, Craigie RJ, et al. Trisomy 18: palliative surgical intervention. Arch Dis Child. 2018; 103(10): 1001, doi: 10.1136/archdischild-2017-313889, indexed in Pubmed: 29449215.

12. Dyer C. Parents fail to overturn ruling not to resuscitate baby BMJ. 2005; 330(7498): 985, doi: 10.1136/bmj.330.7498. 985-b, indexed in Pubmed: 15860816.

13. Jaykar R, Patil S. Indications of ventriculoperitoneal shunt: a prospective study. International Surgery Journal. 2017; 4(4): 1319, doi: 10.18203/2349-2902.isj20171135. 